\title{
MILOVAN MILOVANOVIĆ'S VIEWS ON SERBIAN FOREIGN POLICY AND NATIONAL ISSUES AT THE END OF XIX AND THE BEGINNING OF XX CENTURY
}

\author{
UDC 34(497.11):929 Milovanović M. \\ $327(497.11)^{\prime \prime} 18^{\prime \prime}$
}

\author{
Nenad Anžel \\ University of Belgrade, Faculty of Philosophy, Belgrade, Serbia
}

\begin{abstract}
This paper examines the most important views of the Serbian statesman, a diplomat and a lawyer Milovan Milovanović, and his position of the solution of the Serbian national and state issue in the late 19th and early 20th century. Milovanovic was one of the most educated people of his time in Serbia. As a good connoisseur of the European political scene and international relations, he implemented his ideas first as Minister of Foreign Affairs and later as Prime Minister of the Serbian Kingdom.
\end{abstract}

Key words: Milovan Milovanović, Serbia, Eastern Question, foreign policy, national issue

\section{INTRODUCTION}

Serbian statesman, diplomat and a lawyer Milovan Milovanović was born on the 17th of February 1863, as one of the four children of Đorđe Milovanović, a famous conservative politician and a follower of the Obrenovic dynasty. In his early childhood, he showed a great propensity for reading and learning. In 1873, he enrolled at the Belgrade High School and he was an excellent student throughout his high school education (Ђорђевић, 1997: 2021; Ђорђевић, 1962: 8-9).

After graduating from high school in 1880 with excellent grades, Milovanović enrolled at the Belgrade Higher School. However, in 1881, he moved to Paris to study. In terms of scientific development, Belgrade was a small environment for this ambitious young scholar. He resided in Paris with the Serbian minister Jovan Marinovic ${ }^{1}$, who was an old friend of his father (Ђорђевић, 1997: 22-23).

Received May $18^{\text {th }}, 2020 /$ Accepted June $5^{\text {th }}, 2020$

Corresponding author: Nenad Anžel, MA, PhD candidate at the Faculty of Philosophy, University of Belgrade, Republic of Serbia; e-mail: nenad.anzel@gmail.com

${ }^{1}$ Jovan Marinović (1821-1893) was a Serbian conservative politician and diplomat, Minister of Finance (18561873) and the President of State Council (1861-1873). 
Even at the beginning of his studies, Milovanović showed his interest in and affection for national and international law, economics and finances. At the Faculty of Law in Paris, he regularly attended (inter alia) the lectures given by Professor Louis Renault, an expert in international law, who was later Milovanović's mentor throughout the process of writing and defending his doctoral dissertation. He regularly corresponded with his professor and mentor after graduation, as well as during his diplomatic and political career (Мекензи, 2007: 17).

In early 1885, Milovanović began his doctoral studies in international law. He defended his dissertation titled "Guarantee Contracts in the Nineteenth Century" in January 1888. The committee was chaired by his favorite professor, Louis Renault. The thesis was awarded a gold medal, and Professor Renault delivered a few commendations on the work and the author in the scholarly journal "Archives diplomatiques" (Ђорђевић, 1997: 27-29).

At the time of writing his dissertation, Milovanović was twenty-five. He wrote a large 415-page study in a clear, concise and precise manner. In the paper, he outlined the ideas that would eventually guide him in later political work: realism, utilitarianism and skepticism. Most of the dissertation is in fact the diplomatic history of Europe, from the Vienna Congress to the Berlin Congress, with specific emphasis on the Eastern Question (Ђорђевић, 1997: 29: Ђорђевић, 1962: 15).

Milovanović's youthful views echoed the influences of two academics, the Italian political philosopher and historian Niccolò Machiavelli, and Prussian king Friedrich II Hohenzollern, the enlightened absolutist (Ђорђевић, 1962: 18). Hе accepted pure interest as one of the main criteria in politics. As testified by Slobodan Jovanović ${ }^{2}$, Milovanović personally told him many times that he preferred reading the works of Machiavelli more than the works of other political writers, and that he underlined most of his book "The Prince". Milovanović believed that Machiavellianism alone was the pure truth, and everything else was naivety or hypocrisy. He was a realist in politics; he did not believe in principles and worshiped only success (Јовановић, 1992: 213). Many years later, at the pinnacle of his political and statesman's career, Milovanović expressed his thoughts on this issue in his notes and reflections upon the death of his long-time diplomatic rival, Count Alois Lexa von Aehrenthal: "Success is everything. It justifies everything; everything bows to success; good and bad reputation depends on it. The one who succeeds is great; the one who fails is worth nothing." 3

Even in his doctoral dissertation, Milovanović expressed affinity for studying diplomacy and international relations. Between 1894 and 1898, he had several of his articles published in the scientific journal "Delo", a monthly journal for science, literature and social life. This scientific magazine gathered the very best of the Serbian intelligencia, including some of the well-known poets, writers and scholars of that time (e.g. Aleksa Šantić, Svetozar Ćorović, Janko Veselinović, Jovan Cvijić, Jovan Skerlić, etc.) as well as famous politicians (e.g. Svetislav Simić, Ljubomir Davidović and Ljubomir Stojanović). Until the advent of the Serbian Literary Gazette in 1901, this magazine had a crucial cultural influence on young intellectuals in Serbia (Ђорђевић, 1997: 60).

\footnotetext{
${ }^{2}$ Slobodan Jovanović (1869-1958) was a famous Serbian lawyer, historian and politician. He was the professor at the University of Belgrade Faculty of Law, Rector of the University of Belgrade and the President of the Royal Serbian Academy. During the World War II he was a President of Yugoslav govermentment in exile in London ( 1942-1943 ). ${ }^{3}$ Arhiv Srbije, Lični fond Milovana Milovanovića (Archives of Serbia, Personal fund of Milovan Milovanović): Смрт Еренталова, Beograd, II/II 1912, Fascikla-X, 17.
} 
In the words of Svetislav Simić, Milovanovic's debate "Our foreign policy"4 has become "the catechism of Serbian foreign policy" (Ђорђевић, 1997: 60). In a brief and systematic way, Milovanović conducted an analysis and classified the tasks of Serbian foreign policy. He started with the thesis that the entire destiny of states and peoples, their progress or decline, the way of life, the direction of development, and the ultimate goal they aspire to is the result of the natural forces governing social life and determining the laws by which one lives. However, he points out that it would be a great mistake to draw from this assumption the fatalistic conclusion that one must surrender to destiny without a fight, and that all efforts to fight must be in vain. On the contrary, the first condition for the survival of a nation lies in the constant struggle for life, in initiative and endurance, in the will for the creation of higher cultural ideals, in the readiness to pledge all its strength for defense of its interests and its ideals. "Surrendering to destiny, expecting something from the consequences of the unfolding events with folded hands (without taking any action), implies as much as self-denial, as well as decline and inevitable decay in the near future. The nation which surrenders to its destiny, which indifferently and without participation looks at the events that take place in and around it, which no longer has a sense of the common good, which cannot create any sublime ideals, or which has abandoned them, such a nation has lost one of the necessary prerequisites for its survival; such a nation is heading to its apparent doom and it has already been sentenced to death" (Миловановић, 1997: 245-246).

These natural forces, according to Milovanović, are dual in nature; they have an internal and an external character. The internal natural forces of social organisms are the result of those national traits that trigger a nation's need for defense and self-sustainability. The external natural forces entail the needs of other (foreign) social organisms that strive to ensure their own sustainability and advancement. In practical terms, it ultimately means that if a weaker and inferior state got in the way of the needs of a stronger nation, the smaller (weaker) one would necessarily yield to the needs of the stronger one; and if it were unable to adapt, it would have to disappear from the face of the earth. Based on these hypotheses, Milovanović concludes that each country's foreign policy has a twofold task, two distinctive goals which come from two different sources. In the first place, it must fulfill the tasks arising from the internal needs of the state (e.g. trade, transport, expansion of political power, expansion of state borders, etc.). In the second place, foreign policy has the task of recognizing "external currents" and "foreign" needs and interests that support the survival and further development of one's state. It can fulfill its needs and goals only when it is well acquainted with the goals and directions of all these external developments (Миловановић, 1997: 246-247).

From this point of view, Milovanovic further developed the basic tasks of Serbian foreign policy and the directions it must pursue. He argued that Serbia's foreign policy at the time was not a lonely and isolated phenomenon, and that it was closely linked to the Eastern Question and Austro-Russian relations (Ђорђевић, 1997: 61). The AustroHungarian empire was expanding its influence in the Balkans by all means. By the provisions of the Berlin Treaty from 1878, it occupied Bosnia and Herzegovina and entered the Balkans. Its impact and expansion into the Balkans, as well as its expansive pursuits of the Aegean, was not obstructed. As Milovanovic noted, the Austrian Drang nach Osten $^{5}$ was one of the basic principles of Austrian diplomacy at the time. He drew a

\footnotetext{
${ }^{4}$ The debate was printed in the scientific journal Delo in 1894.

5 "Drang nach Osten" ("Striving for the East") indicates the intentions of Germany and Austria-Hungary to expand east by annexation, the creation of subordinate states and the establishment of interest spheres. In both empires, this motto
} 
parallel between the former Italy, i.e. Lombardy and Venice, which were under a strong Austrian influence until 1866 when Austria-Hungary was overpowered and pushed out of these territories, after being defeated in the war with Prussia and in the Balkan wars, principally in Bosnia and Herzegovina. The Austro-Hungarian policy aimed to deprive all the Balkan states of their independent lives and to bring them in line with its own sphere of interest (Миловановић, 1997: 250-251).

Milovanović stipulated that the future of all nations in the Balkan Peninsula depended on the future of two Balkan states: Serbia and Bulgaria. Milovanović noted that AustriaHungary did not have to exert special efforts to trigger disputes between the two states. The seeds of discord were sown in the Serbo-Bulgarian war of 1885 which, he believed, disrupted the possibility of genuine Serbian-Bulgarian collaboration for many years to come (Миловановић, 1997: 253). The evidence that Milovanović was completely right in his assessment of these historical events may be found in his notes from 1912, when he was involved in making an alliance with Bulgaria. On that occasion, he noted that "the first and foremost reason is that Serbia is more resolved than any other Balkan state to seek its future in the alliance and solidarity with the Balkan states, primarily in alliance with Bulgaria. For this reason, the "Augaria", which is generally ill-disposed towards such a rapprochement of the Balkan countries, is most apprehensive of the Serbo-Bulgarian agreement and constantly seeks to isolate Serbia from other Balkan countries..."7

In Milovanović's opinion, Serbia's primary task is not only to preserve its state independence and territory from being attacked by an aggressive neighbor but also to put all its strength into the function of executing Serbian national thought, liberating all Serbs and uniting them in a single state union. Serbia must not neglect the general interests of Serbianhood. For Serbia, it is the existential question: to be or not to be (Миловановић, 1997: 253-254). It must not in any way suspend its action and reduce its plans to the former state border. However, Milovanovic is aware that the Serbian question and the question of all the Balkan Slavs, and primarily a common Serbo-Bulgarian issue, cannot be solved solely according to the interests and desires of those nations, and particularly not by means at their disposal at that moment. Without great nations and satisfying their great interests, there are no solutions to the so-called Eastern question, which also includes the fate of the Serbian and Bulgarian people (Миловановић, 1997: 256).

Milovanović indicated that Serbia would not have its final geographical appearance until the Eastern Question was resolved. He also noted that Russia was the only great nation willing to fight, to resolve the issue for the benefit of the Balkan peoples. However, the Berlin Congress made it very clear that Russia was not able to solve the Eastern question on its own. Of all other great nations, Russia could count only on France, under certain circumstances. He recalled the fact that Russia had success in the East only when it had France by its side. So, the alliance of Russia and France would be one of the first conditions

played a most prominent role in the 1980s. Representatives of this idea were the holders of the highest authorities, bureaucracy, industry, commerce, and intelligence. The idea was more widespread and more prevalent in Germany and was preferred by representatives of German convictions in the Austrian part of the monarchy. Sеe: Андреј Митровић, Продор на Балкан. Србија у плановима Аустро-Угарске и Немачке 1908-1918, Београд 2011, 11.

${ }^{6}$ In the original notes of Milovan Milovanovic, kept in the Archives of Serbia as part of his Personal Fund, the author repeatedly refers to Austria-Hungary as "Augarska" (Aungaria) The parts cited in this paper are quoted in the original, as written by the author himself in the notes. (Cf. N.A.)

${ }^{7}$ Arhiv Srbije, Lični fond Milovana Milovanovića, Београд, 19.I 1912, Аустроугарска и Балканско подунавље, F-X, 5-6. 
for resolving the fate of the Balkan peoples in their favor. As Milovanović knew that the agreement between the two great nations had already been signed ${ }^{8}$, he indirectly pointed to the Serbian government which direction Serbian foreign policy should pursue and, above all, that Serbia should greatly benefit from being taken under the wing of those great powers in the future (Јовановић, 1992: 233).

Considering such a standpoint on this issue, Milovan Milovanović was classified as Russophile. However, it is important indicate that, unlike the earlier Russophilism of Serbian liberals and radicals who blindly believed in the almighty Russia and were ready to follow it as soon as it appeared in the Balkans, Milovanović's Russophilism had its roots in his realistic assessment of international circumstances at the time. He believed that Russia was strong enough only when supported by with France, which was the prerequisite for associating Serbia's future destiny with Russia (Јовановић, 1992: 233). This fact shows Milovanović's diplomatic potential for understanding real politics, which particularly came to the fore when he was appointed to serve as head of Serbian diplomacy (Minister of Foreign Affairs). Milovanović stated that Russian policy in the Balkans, aimed at creating and developing nation-states, was not a transient temporary policy. The Serbian diplomat claimed that Russian policy was so stable and permanent that it could already be considered a well-established and well-grounded tradition of the Russian program on the Eastern Question. Russia had been working on this issue since 1812, exerting its influence in a number of historical events: the Peace Treaty of Bucharest in 1812, the Akkerman Convention in 1826, the Treaty of Edirne in 1829, the Crimean War of 1853-1856, and the Great Eastern Crisis of 1875-1878. Milovanović said that all these were indicators that the creation and development of nation-states in the Balkans safely and securely leads Russia to achieving its goals in the Eastern Question (Миловановић, 1997: 257-258).

In pursuing their national interests with the assistance of Russia, the Balkan nations have to pay attention to two things: first, that their national ideals do not contradict Russian goals and exceed the line of purely Russian interests, and secondly, the Balkan countries have to show that they are capable of "standing on their own feet", living their lives and responding to the tasks set forth by Russia, which upheld their creation and development. Milovanovic indicated that Russia's foreign policy in the Balkans rested on assessing the circumstances that would enable Russia to become the master of the two straits: the Bosphorus and the Dardanelles. He thought that it could be achieved either directly by occupying the territories of the Balkan Peninsula or indirectly by creating barriers (in the form of independent Balkan states) against the invasion from Central Europe. By resorting to the first solution, Russia would disrupt the existing balance of forces on the European continent and invoke the reaction of other major powers. The second solution would be more favorable to Russia; while defending the Russian interests, the Balkan peoples would also protect their own (Миловановић, 1997: 260-262).

\footnotetext{
${ }^{8}$ In August 1891, a secret political agreement between the two powers was concluded on a common contribution to European peace. French Prime Minister Freycinet demanded that the treaty be specified by signing a military agreement. Russian Foreign Minister Girs opposed, but senior Russian military circles were in favor, and the treaty was signed in August 1892. The treaty obliged both parties to provide mutual assistance in case of attack by one of the members of the Triple Alliance. The treaty was ratified by Russian Tsar Alexander III in 1893, and it was signed by the French in January 1894. This was the first step in the creation of the second block of European powers - the Grand Entente. Seе: Чедомир Попов, Грађанска Европа (1770-1914). Друитвена и политичка историја Европе (1871-1914), књ.III, Београд 2010 , 264-265.
} 
"Russia has always played the first and foremost role in the Eastern Question. Its policy was relevant and authoritative in different phases that the Eastern Question went through. The action of major European powers in the Balkan Peninsula had always revolved around Russia, irrespective of they supported or opposed Russian policies. Russia's position in the interplay of the great European powers, its importance and its impact in the overall European policy significantly determined the specific developments in resolving the South Slavs' Question in general, as well as the prospects of resolving the Serbian Question in particular. Therefore, the question of crucial importance is whether the ultimate goals of Russian policy correspond or conflict with our national ideals" (Миловановић, 1894: 249).

The Austro-Hungarian Empire was another great power, which had quite different interests in the Balkans than Russia. After the Congress of Berlin in 1878, the "Dual Monarchy" grew increasingly aggressive in its plans for Serbia. Milovanović noted that the pressure from the northern neighbor was a heavy burden on Serbia's interests. The occupation of Bosnia and Herzegovina by the Austro-Hungarian Empire made AustroHungary the main opponent of the Serbian national interests because any action taken by Austro-Hungary would inevitably affect Serbia's state interests. Milovanović noted that Serbia had to be cautious to avoid anything that could give rise to Austro-Hungary's action and repression. By observing its obligations arising from international treaties towards its northern neighbor, Serbia should make sure that, in the event of any possible dispute or misunderstanding, it can entrust its cause to the public opinion and judgement of great powers without any hesitation (Миловановић, 2007: 262-263). Similar standpoints may be found in Milovanović's notes from 1911, which bear witness that Serbia and its statesmen were ready to resolve disputes with Austria-Hungary in a peaceful way. Milovanović noted that Serbia was essentially in a constant state of war with Austro-Hungary, and suggested that Serbia's attitude towards the northern neighbour should be similar to the stance taken by Prince Miloš towards Turkey: "Not only is it essential to fully maintain correct and regular relations (with Austria-Hungary) but also to satisfy vanities (...) by tolerance and small favors where national interests are not very at issue." In practice, this implied that Serbia's attitude towards Austria-Hungary should be rational and realistic. Milovanović suggested that Serbia should advocate for those interests that were attainable under favorable circumstances, while concurrently ensuring that standing for its interests would not be designated as "irreconcilable aggression"?

Last but not least, his notes and reflections on different political and social issues include a number of warning remarks. Milovanović warned that, if the ideas of Serbian national identity (Serbianhood) were the subject matter of serious consideration, Serbia should never forget that it is only Russia that could have an interest in helping Serbia achieve its plans (Миловановић, 1894: 257). Thus, Serbia should do its best to provide indisputable evidence that it is prepared to safeguard its independence, particularly in view of the AustroHungarian aspirations; moreover, it should clearly demonstrate that Russia can count on it as a reliable and loyal ally for the successful resolution of the Eastern Question. At the same time, Serbia should not forget that Austria-Hungary is the main opponent of Serbia and Serbianhood. Finally, Milovanović wisely noted that great politics has two principles that complement each other: "the ability to wait and, after waiting for the most convenient and favourable moment, the ability to decide" (Миловановић, 1997: 264-265).

\footnotetext{
${ }^{9}$ Arhiv Srbije, Lični fond Milovana Milovanović: Гаштајн, 8. VIII 1911, Аустрија и Србија, F-IV, 47.
} 


\section{REFERENCES}

Ђорђевић, Д. (1997). Портрети из новије српске историје, Београд, БИГЗ

Ђорђевић, Д. (1962). Милован Миловановић, Београд, Просвета

Јовановић, С. (1992). Милован Миловановић, Из историје књижевности I, Београд, БИГЗ

Мекензи, Д. (2007). Милован Миловановић - српски дипломата и државник, Београд, Правни факултет, Центар за публикације : Досије

Миловановић, М. (1894). Наша спољна политика, Дело, четврта књига, Београд

Миловановић, М. (1997). Државно право и начела спољне политике краљевине Србије, приредили: Р. Стојановић, Д. Стојановић, Београд: "Филип Вишњић"

Митровић, А. (2011). Продор на Балкан. Србија у плановима Аустро-Угарске и Немачке 1908-1918, Београд, Завод за уџбенике

Попов, Ч. ( 2010 ). Грађанска Европа (1770-1914). Друштвена и политичка историја Европе (18711914), књ. III, Београд, Завод за уџбенике

Arhiv Srbije, Lični fond Milovana Milovanovića (1863-1912), priredila A. Kos Vujović, Beograd: Arhiv Srbije, 2014, https://catalog.princeton.edu/catalog/SCSB-5787967,

https://arhivsrbije.rs/en/fonds/personal-fonds

\section{POGLEDI MILOVANA MILOVANOVIĆA \\ O SRPSKOJ SPOLJNJOJ POLITICI I NACIONALNOM PITANJU KRAJEM XIX I POČETKOM XX VEKA}

Rad proučava najvažnije stavove srpskog državnika, diplomate i pravnika Milovana Milovanovića $i$ njegovo viđenje rešenja srpskog nacionalnog i državnog pitanja krajem XIX i početkom XX veka. Milovanović je spadao u red najobrazovanijih ljudi svoga vremena u Srbiji. Kao dobar poznavalac evropske politicke scene i međunarodnih odnosa, on je te svoje ideje sprovodio najpre kao ministar inostranih dela, a kasnije i kao predsednik vlade Kraljevine Srbije.

Ključne reči: Milovan Milovanović, Srbija, Istočno pitanje, spoljna politika, nacionalno pitanje 